\title{
Article \\ The Multifunctionally Graded System for a Controlled Size Effect on Iron Oxide-Gold Based Core-Shell Nanoparticles
}

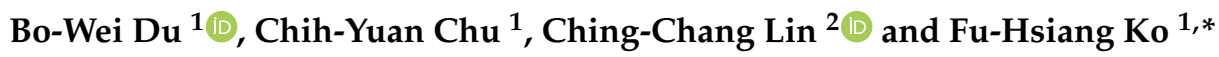 \\ 1 Department of Materials Science and Engineering, National Yang Ming Chiao Tung University, \\ Hsinchu 30010, Taiwan; duu.mse04g@nctu.edu.tw (B.-W.D.); dv8962@hotmail.com (C.-Y.C.) \\ 2 Research Center for Advanced Science and Technology (RCAST), The University of Tokyo, 4-6-1 Komaba, \\ Meguro-ku, Tokyo 153-8904, Japan; Lin@dsc.rcast.u-tokyo.ac.jp \\ * Correspondence: fhko@mail.nctu.edu.tw; Tel.: +886-35712121 (ext. 55803)
}

\section{check for} updates

Citation: Du, B.-W.; Chu, C.-Y.; Lin, C.-C.; Ko, F.-H. The Multifunctionally Graded System for a Controlled Size Effect on Iron Oxide-Gold Based Core-Shell Nanoparticles. Nanomaterials 2021, 11, 1695. https://doi.org/10.3390/ nano11071695

\section{Academic Editors: Alexandru}

Mihai Grumezescu, Oana Gherasim, Jiye (James) Fang and Olivier Sandre

Received: 18 May 2021

Accepted: 25 June 2021

Published: 28 June 2021

Publisher's Note: MDPI stays neutral with regard to jurisdictional claims in published maps and institutional affiliations.

Copyright: (c) 2021 by the authors. Licensee MDPI, Basel, Switzerland. This article is an open access article distributed under the terms and conditions of the Creative Commons Attribution (CC BY) license (https:// creativecommons.org/licenses/by/ $4.0 /)$.

\begin{abstract}
We report that $\mathrm{Fe}_{3} \mathrm{O}_{4} @ \mathrm{Au}$ core-shell nanoparticles (NPs) serve as a multifunctional molecule delivery platform. This platform is also suitable for sensing the doxorubicin (DOX) through DNA hybridization, and the amount of carried DOX molecules was determined by size-dependent $\mathrm{Fe}_{3} \mathrm{O}_{4} @ \mathrm{Au}$ NPs. The limits of detection (LODs) for DOX was found to be $1.839 \mathrm{nM}$. In our approach, an Au nano-shell coating was coupled with a specially designed DNA sequence using thiol bonding. By means of a high-frequency magnetic field (HFMF), a high release percentage of such a molecule could be efficiently achieved in a relatively short period of time. Furthermore, the thickness increase of the Au nano-shell affords $\mathrm{Fe}_{3} \mathrm{O}_{4} @ \mathrm{Au}$ NPs with a larger surface area and a smaller temperature increment due to shielding effects from magnetic field. The change of magnetic property may enable the developed $\mathrm{Fe}_{3} \mathrm{O}_{4} @ \mathrm{Au}$-dsDNA/DOX NPs to be used as future nanocarrier material. More importantly, the core-shell NP structures were demonstrated to act as a controllable and efficient factor for molecule delivery.
\end{abstract}

Keywords: molecular carriers; magnetic nanoparticles; core-shell nanostructure; aptamer; size effect

\section{Introduction}

The past four decades have seen the foundations established for nanotechnologies to deliver therapeutic and diagnostic agents in one securer and more effective manner [1-4]. With the development of nanotechnology, various nanoparticles (NPs), nanocarriers, or conjugates have been developed for various biomedical applications. Owing to their specific configurational properties and favorable physical-chemical characteristics [5,6], the goal of modulating both the pharmacokinetic and pharmacodynamic profiles of drugs can be achieved to enhance their therapeutic index [7-9]. In particular, inorganic NPs have gradually become more popular in recent years. Integration of magnetic iron oxide $\left(\mathrm{Fe}_{3} \mathrm{O}_{4}\right)$ and $\mathrm{Au}$ NPs can be used in hyperthermia [10], catalysis [11], and surface modification [12]. Furthermore, $\mathrm{Fe}_{3} \mathrm{O}_{4}$ NPs have been used as carriers for cell imaging [13] and drug delivery systems [14] due to their apparent superparamagnetism, high specific surface area, significant colloidal stability, and excellent biocompatibility $[15,16]$. An Au coating onto magnetic NPs is another appealing hybrid system $[17,18]$. Except for single-component materials, the multicomponent materials demonstrate unique property. With an Au coating, magnetic NPs can be functionalized through thiol linkages. The Au coating also renders the magnetic NPs with a surface plasmon resonance (SPR) effect such that conduction electrons have resonant oscillation at the interface between signed permittivity materials when exposed to incident light. Through proper selection of the particle size, Au colloidal nanospheres display strong SPR absorption intensity in the near-infrared (NIR) region [19], enabling their use for computed tomography (CT) imaging [20] and magnetic resonance imaging (MRI) [21] of cancer cells or other biological systems. 
For cancer diagnosis and medical treatment, it is necessary to devise a therapy that is capable of integrating both target drug delivery systems into cancer cells and that has fewer effects on normal cells. In particular, for the fewest side effects, it is crucial to focus the drug on the tissues of interest in the meantime decreasing the relative concentration of the medication in other tissues so that molecule that can specifically bind to the target cell [22,23]. For instance, once antibodies link with antigens and the antibody Fc domains engage Fc receptors on the immune effector cell surfaces [24], the antibody-dependent cellular cytotoxicity appears, which triggers the immune system to kill cancer cells after antibodies bind to antigens [25]. Antibodies are also controlled by complement-dependent cytotoxicity, which is another cell-killing technique [26]. Aptamers, as artificial nucleic acid ligands formed forward specific targets, have testified to a novel kind of ligands that rival antibodies in their potential for therapeutic and diagnostic applications [27,28]. Alternatively, aptamers provide more attractive properties on therapeutic agents than antibodies [29]. For example, aptamers have better stability and can stand for much more extreme environments, such as high temperatures [30,31]. In addition, due to their better diversity in binding targets, aptamers can be designed not only for targeting but also for functioning as drug carriers [32]. Previous studies have also indicated that aptamers are absent of immunogenicity and can be chemically modified to enhance the performance toward nucleases or lengthen the period of their blood circulation [33]. In addition to these properties of the materials, NP size is a vital characteristic that has been indicated to have a great effect on biomedical applications [34,35]. In addition to the SPR effect of NPs as mentioned, previous reports showed that magnetic NPs of different diameters corresponded with different MRI signals [36], and this effect was attributed to the change in the NP surface area. Jiang et al. showed the relationship between the NP diameter and the amount of protein that could be coupled on the NP surface [37]. Therefore, for accurate theranostics of cancer cells or targeting-type drug delivery systems, it is essential to discuss the size effect of nanoparticles, and the effect that may be related to the shielding effect on magnetic property [38-40].

In the present work, we reported the synthesis of $\mathrm{Fe}_{3} \mathrm{O}_{4} @ \mathrm{Au}$ core-shell NPs, which serve as substrates for further application in multifunctional molecule delivery systems. Both magnetic and optical properties derived from the $\mathrm{Fe}_{3} \mathrm{O}_{4} \mathrm{NPs}$ and the Au nano-shells were studies. The specially designed CG-rich fragments by triggering with HFMF as the purpose of the actuator, and the designed $\mathrm{Fe}_{3} \mathrm{O}_{4} @ \mathrm{Au}-\mathrm{dsDNA}$ material can carry DOX (as the anticancer drug). Hence, both molecule loading and specific target application could be achieved (Scheme 1) [41]. In addition, we synthesized $\mathrm{Fe}_{3} \mathrm{O}_{4} @ \mathrm{Au}$ NPs material with various size distributions by adjusting the concentration of the reduction agent. The different $\mathrm{Au}$ nano-shell thicknesses were studied with respect to the magnetism, surface area, and other physical functions. Such an approach is beneficial to understanding the basic property of our molecule carrier for future targeted drug delivery and cancer therapy. The formation of a larger surface area, which leads to a higher DNA binding concentration, carries more DOX molecules and results in a difference in chemotherapeutic ability. The cytotoxicity of ds-DNA-conjugated $\mathrm{Fe}_{3} \mathrm{O}_{4} @ \mathrm{Au}$ drug carriers was investigated with respective to cell death and biocompatibility of our carriers. 


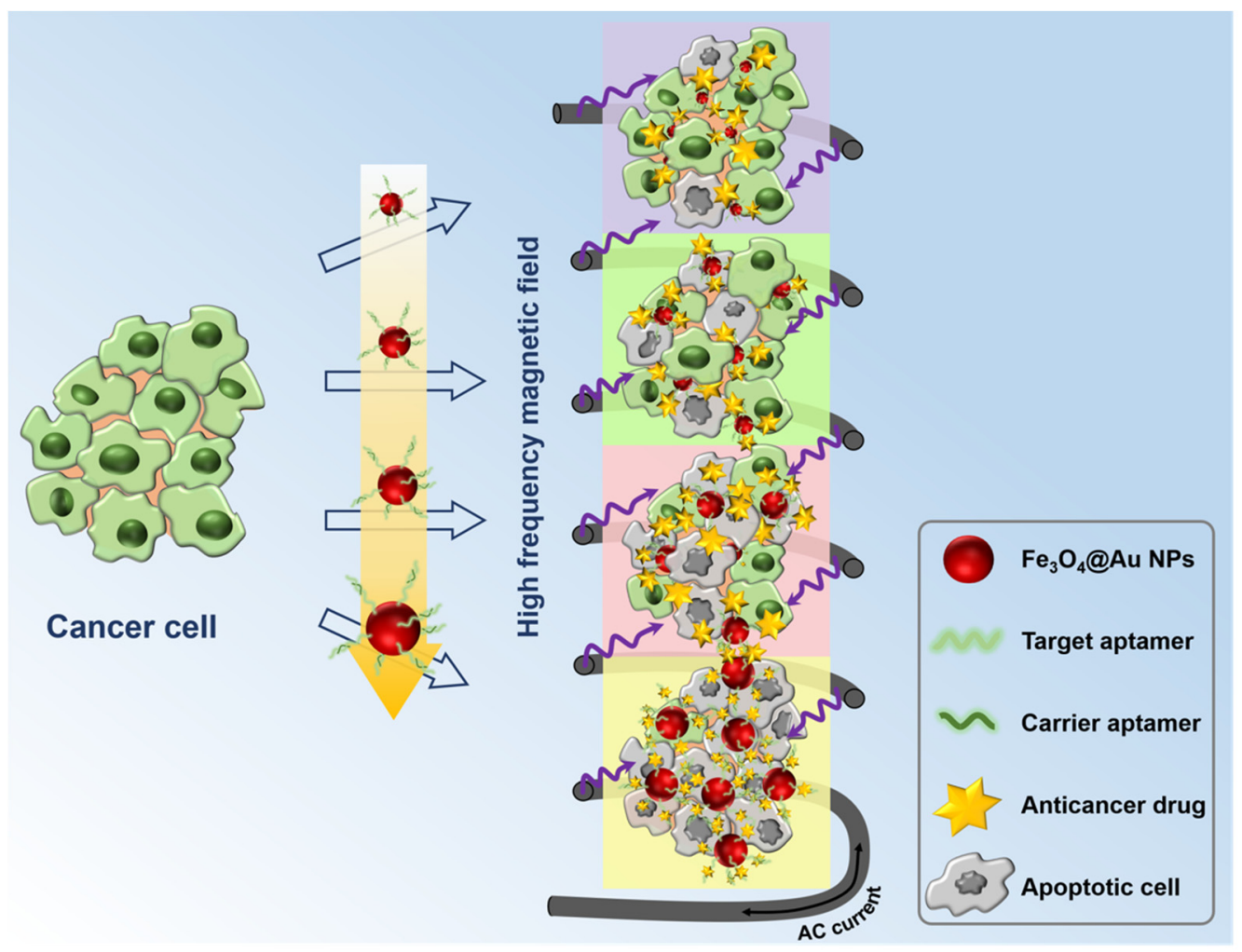

Scheme 1. Schematic illustration of the synthesis of the multifunctional molecule delivery system and its further applications.

\section{Materials and Methods}

\subsection{Materials}

Iron(II) chloride tetrahydrate $\left(\mathrm{FeCl}_{2} \cdot 4 \mathrm{H}_{2} \mathrm{O}, 98 \%\right)$, iron(III) chloride hexahydrate $\left(\mathrm{FeCl}_{3} \cdot 6 \mathrm{H}_{2} \mathrm{O}, 98 \%\right)$, and hydroxylamine hydrochloride $\left(\mathrm{NH}_{2} \mathrm{OH} \cdot \mathrm{HCl}, 99 \%\right)$ were purchased from Alfa Aesar (Lancashire, UK). Hydrogen chloride ( $\mathrm{HCl}, \geq 99 \%)$, Au(III) chloride trihydrate $\left(\mathrm{HAuCl}_{3} \cdot \mathrm{H}_{2} \mathrm{O}, \geq 49 \%\right)$, doxorubicin hydrochloride (DOX, $\mathrm{C}_{27} \mathrm{H}_{29} \mathrm{NO} \cdot \mathrm{HCl}, \geq 98 \%$ ), phosphate-buffered saline (PBS, 99.18\%), tetramethylammonium hydroxide (TMAOH, $\geq 97 \%$ ) and dimethyl sulfoxide (DMSO, $\geq 99.9 \%$ ) were purchased from Sigma (MO, USA). Sodium hydroxide $(\mathrm{NaOH}, 97 \%)$ and trisodium citrate dihydrate $\left(\mathrm{C}_{6} \mathrm{H}_{5} \mathrm{Na}_{3} \mathrm{O}_{7} \cdot 2 \mathrm{H}_{2} \mathrm{O}\right.$, $98 \%$ ) were obtained from SHOWA (Tokyo, Japan). Tetramethylammonium hydroxide $\left(\left(\mathrm{CH}_{3}\right)_{4} \mathrm{NOH}, 25 \% \mathrm{w} / w\right.$ in aqueous solution) was used as purchased from Fluka (Heidelberg, Germany). Dulbecco's modified Eagle's medium (DMEM) was purchased from Biowest (MO, USA). Trypsin and tetrazolium salt 3-(4,5-dimethylthiazol-2-yl)-2,5-diphenyltetrazolium bromide (MTT, $\geq 99.9 \%$ ) were purchased from Thermo Scientific (MA, USA) and Bersing Bioscience Technology (North District, Taiwan), respectively. Oligonucleotides were obtained from MDBio Inc. (Taipei, Taiwan) and the target DNA containing the $5^{\prime}$-AAAAAAAA AAAAAAATCGTCGTCGTCGTCGTCGAAAAAAAAAAAAAAAAAGCAGTTGATCGTT TGGATACCCTGG-3' sequence and the complementary DNA containing the $3^{\prime}$-TTTAGCAG CAGCAGCAGCAGCTT-5' sequence were hybridized to form double-strand DNA. A Milli-Q deionized water system provided deionized water in all processes, which with a resistivity more than $18 \mathrm{M} \Omega \cdot \mathrm{cm}$. HeLa cells (a human cervical carcinoma cell line; Sigma, MO, USA) and MCF-7 (Sigma, MO, USA) cells were used for the cell viability test.

\subsection{Preparation of Superparamagnetic $\mathrm{Fe}_{3} \mathrm{O}_{4} \mathrm{NPS}$}

The $\mathrm{Fe}_{3} \mathrm{O}_{4}$ NPs were prepared in an aqueous solution using the coprecipitation method [42] according to the following procedure: $5.4 \mathrm{~g}(20 \mathrm{mmol}) \mathrm{FeCl}_{3} \cdot 6 \mathrm{H}_{2} \mathrm{O}$ followed by $2.0 \mathrm{~g}(10 \mathrm{mmol}) \mathrm{FeCl}_{2} \cdot 4 \mathrm{H}_{2} \mathrm{O}$ were dissolved in $25 \mathrm{~mL}$ of $6 \mathrm{M} \mathrm{HCl}$ (aq). The solution was 
added dropwise into $25 \mathrm{~mL}$ of $1.5 \mathrm{M} \mathrm{NaOH}$ solution with energetic stirring, and the black precipitates were isolated by a magnet and washed twice with both deionized water and $0.1 \mathrm{M}$ tetramethylammonium hydroxide pentahydrate. The particles were separated by centrifugation at 14,000 rpm for $30 \mathrm{~min}$, meanwhile, the ultimate product was dispersed in $250 \mathrm{~mL}$ of $0.1 \mathrm{M}$ TMAOH. The $6.5 \mathrm{mg} / \mathrm{mL}$ magnetic NP solution was stored at room temperature under benchtop conditions.

\subsection{Preparation of $\mathrm{Fe}_{3} \mathrm{O}_{4} @ A u$ NPs}

$\mathrm{Fe}_{3} \mathrm{O}_{4} @ \mathrm{Au}$ core-shell NPs were synthesized by deposition of $\mathrm{Au}$ on the performed $\mathrm{Fe}_{3} \mathrm{O}_{4}$ NPs using a modification of Lyon's iterative hydroxylamine seeding procedure in three steps. First, $1 \mathrm{~mL}$ of the $\mathrm{Fe}_{3} \mathrm{O}_{4} \mathrm{NP}$ solution was mixed by vortexing with $1 \mathrm{~mL}$ of $0.1 \mathrm{M}$ sodium citrate for $10 \mathrm{~min}$. Next, $20 \mathrm{~mL}$ of deionized water added into the solution, and then $100 \mu \mathrm{L}$ of $80 \mathrm{mM} \mathrm{NH} \mathrm{N}_{2} \mathrm{OH} \cdot \mathrm{HCl}$ was added to this solution. Finally, $2 \mathrm{~mL}$ of $1 \% \mathrm{HAuCl}_{4}$ solution was added dropwise with stirring. The uncoated $\mathrm{Fe}_{3} \mathrm{O}_{4} \mathrm{NPs}_{\text {sere }}$ removed by centrifugation at $6000 \mathrm{rpm}$ for $5 \mathrm{~min}$.

Size distribution of $\mathrm{Fe}_{3} \mathrm{O}_{4} @ \mathrm{Au}$ core-shell NPs was synthesized by alternating the amount of sodium citrate and $\mathrm{NH}_{2} \mathrm{OH} \cdot \mathrm{HCl}$. The conditions of each NP size are shown below (Table 1).

Table 1. Properties of different NP sizes.

\begin{tabular}{ccccc}
\hline Particle Size $(\mathbf{n m})$ & $\mathrm{Fe}_{\mathbf{3}} \mathbf{O}_{\mathbf{4}}(\mathbf{m L})$ & $\mathbf{C}_{\mathbf{6}} \mathbf{H}_{5} \mathbf{N a}_{\mathbf{3}} \mathbf{O}_{\mathbf{7}}(\boldsymbol{\mu L})$ & $\mathbf{N H}_{\mathbf{2}} \mathbf{O H} \cdot \mathbf{H C l}(\boldsymbol{\mu L})$ & $\mathbf{H A u C l}_{\mathbf{4}}(\mathbf{m L})$ \\
\hline 25.9 & 1 & 1600 & 68 & 2 \\
33.1 & 1 & 1400 & 80 & 2 \\
39.5 & 1 & 1000 & 100 & 2 \\
47.7 & 1 & 800 & 100 & 2 \\
59.5 & 1 & 600 & 100 & 2 \\
\hline
\end{tabular}

\subsection{Hybridization of Double-Stranded Oligonucleotides (dsDNA)}

The single-stranded DNA (ssDNA) was added to TE buffer $(10 \mathrm{mM}$ Tris- $\mathrm{HCl} / 1 \mathrm{mM}$ EDTA)/50 mM NaCl with pipetting to form an ssDNA solution. A15T3 dsDNA was hybridized with A15 ssDNA and T3 ssDNA sequences at a 1:1 molar ratio in a large water bath heated to $95^{\circ} \mathrm{C}$ for $10 \mathrm{~min}$ and then cooled down to room temperature. The obtained dsDNA was stored at $-20^{\circ} \mathrm{C}$.

\subsection{Preparation of $\mathrm{FFe}_{3} \mathrm{O}_{4} @ A u \mathrm{NPs}-d_{s} \mathrm{DNA}$ and DOX-Intercalated $\mathrm{Fe}_{3} \mathrm{O}_{4} @ A u$ NPs-dsDNA}

One milliliter of the $0.1 \mathrm{mg} / \mathrm{mL} \mathrm{Fe}_{3} \mathrm{O}_{4} @ \mathrm{Au} \mathrm{NP}$ solution was mixed with $10 \mu \mathrm{L}$ of the $50 \mathrm{mM}$ dsDNA at room temperature for $6 \mathrm{~h}$. After being centrifuged, the residual product was washed twice to remove unbound dsDNA and then resuspended in $1 \mathrm{~mL}$ of deionized water.

For DOX molecule loading, $1 \mathrm{~mL}$ of the $0.1 \mathrm{mg} / \mathrm{mL} \mathrm{Fe}_{3} \mathrm{O}_{4} @ \mathrm{Au}$ NPs-dsDNA was mixed with $5 \mu \mathrm{L}$ of $1.72 \mathrm{mM}$ DOX at room temperature for $3 \mathrm{~h}$. After the reaction, the solution was centrifuged at 11,500 rpm for $15 \mathrm{~min}$ to remove unintercalated DOX, and the pellet was resuspended in $1 \mathrm{~mL}$ of deionized water.

\subsection{Characterization of the NPS}

The morphology and structure of the $\mathrm{Fe}_{3} \mathrm{O}_{4}$ and $\mathrm{Fe}_{3} \mathrm{O}_{4} @ \mathrm{Au}$ NPs were determined by transmission electron microscopy (TEM, JEOL, JEM-2010, Akishima, Japan) and scanning electron microscopy (FE-SEM, JEOL-6700, Akishima, Japan). UV-Vis spectroscopy (HITACHI, U-3310, Tokyo, Japan) was used to determine the Au nano-shell coverage and the size of the $\mathrm{Fe}_{3} \mathrm{O}_{4} @ \mathrm{Au}$ NPs. Energy-dispersive X-ray spectroscopy (Oxford-Link ISIS 300 energy-dispersive X-ray, High Wycombe, UK) was used to analyze the NP elemental distribution under TEM. X-ray diffraction signals of the NPs were obtained by X-ray diffraction (XRD, X'Pert PRO MRD system, Almelo, Netherlands). Fluorescence spectroscopy was used to measure the DOX released from different $\mathrm{Fe}_{3} \mathrm{O}_{4} @ \mathrm{Au} \mathrm{NP}$ carriers using a 
fluorescence spectrophotometer (HITACHI, F-7000, Tokyo, Japan). The superconducting quantum interface device vibrating sample magnetometer (SQUID, MPMS-XL, CA, USA) was used for estimating the magnetic properties of the NPs. The high-frequency magnetic field (HFMF) with a frequency of $50 \mathrm{kHz}$ and a magnetic field strength $(\mathrm{H})$ of $8 \mathrm{kA} / \mathrm{m}$ was used for providing an oscillating magnetic field to heat the magnetic materials.

\subsection{Molecule Release by Diffusion and under HFMF}

For testing the DOX molecule release, $1 \mathrm{~mL} 0.1 \mathrm{mg} / \mathrm{mL}$ of $\mathrm{Fe}_{3} \mathrm{O}_{4} @ \mathrm{Au} \mathrm{NPs}-\mathrm{dsDNA} /$ DOX was placed in the $37^{\circ} \mathrm{C}$ water bath, DOX was released slowly from dsDNA. The samples were taken out of the water bath at different times and centrifuged to collect the supernatant immediately.

Each size of $\mathrm{Fe}_{3} \mathrm{O}_{4} @ \mathrm{Au} \mathrm{NPs}-\mathrm{dsDNA} / \mathrm{DOX}$ was put in the center of the loop of HFMF without any contact over different time periods. After treating with HFMF, the sample was removed immediately, and the released molecules were separated with nanoparticles through centrifugation at $14,000 \mathrm{rpm}$ for $30 \mathrm{~min}$.

\subsection{In Vitro Cytotoxicity Assay of $\mathrm{Fe}_{3} \mathrm{O}_{4} @ A u$ NPs-dsDNA and $\mathrm{Fe}_{3} \mathrm{O}_{4} @ A u$ NPs-dsDNA/DOX}

HeLa cells were cultured in DMEM supplemented with $10 \%$ fetal bovine serum and $1 \%$ penicillin-streptomycin and then incubated in humidified air containing a $5 \% \mathrm{CO}_{2}$ atmosphere at $37^{\circ} \mathrm{C}$ and changed every 2.5 d. $\mathrm{Fe}_{3} \mathrm{O}_{4} @ \mathrm{Au}$ NPs, $\mathrm{Fe}_{3} \mathrm{O}_{4} @ \mathrm{Au}$ NPs-dsDNA, and $\mathrm{Fe}_{3} \mathrm{O}_{4} @ \mathrm{Au}$ NPs-dsDNA/DOX of each size were prepared, and $\mathrm{Fe}_{3} \mathrm{O}_{4} @ \mathrm{Au}$ NPs were incubated with Tween $20(0.05 \%)$ to avoid aggregation in the medium. Subsequently, NPs were dissolved in DMEM after centrifugation at $6000 \mathrm{rpm}$ for $5 \mathrm{~min}$.

After detached with trypsin, 5000 cells were cultured in 96-well plates with $200 \mu \mathrm{L}$ DMEM for $24 \mathrm{~h}$ to assign the cells to be linked with the plate. The medium was supplemented with $1 \%$ penicillin-streptomycin and without fetal bovine serum in DMEM. After $24 \mathrm{~h}$ of incubation, the DMEM suspension containing the NPs $(0.1 \mathrm{mg} / \mathrm{mL})$ was substituted for the medium, and the cells were further incubated for $24 \mathrm{~h}$. Subsequently, $100 \mu \mathrm{L}$ of the medium was eliminated, and $10 \mu \mathrm{L}$ of the $5 \mathrm{mg} / \mathrm{mL}$ MTT was added for another $4 \mathrm{~h}$ of incubation. Then, all solutions were removed and replaced with $100 \mu \mathrm{L}$ DMSO solution. The quantification of cell situation was observed using an ELISA plate reader at a wavelength of $570 \mathrm{~nm}$.

\subsection{Size Effects on Molecule Delivery under HFMF}

HeLa cells were cultured in DMEM added in 10\% fetal bovine serum and $1 \%$ penicillinstreptomycin. Then, the cells were incubated in humidified air containing a $5 \% \mathrm{CO}_{2}$ atmosphere at $37^{\circ} \mathrm{C}$ and changed every $2.5 \mathrm{~d}$. Each $\mathrm{Fe}_{3} \mathrm{O}_{4} @ \mathrm{Au}$ NPs-dsDNA/DOX $(0.1 \mathrm{mg} / \mathrm{mL})$ size was dissolved in DMEM after centrifugation at $6000 \mathrm{rpm}$ for $5 \mathrm{~min}$. After being detached with trypsin, 5000 cells were added to $200 \mu \mathrm{L}$ DMEM containing $\mathrm{Fe}_{3} \mathrm{O}_{4} @ \mathrm{Au}$ NPs-dsDNA/DOX in an Eppendorf tube. The Eppendorf tube was placed in the center of the loop of the HFMF without any contact for $7 \mathrm{~min}$, and then the tube was removed immediately. DMEM with $\mathrm{Fe}_{3} \mathrm{O}_{4} @ \mathrm{Au}$ NPs-dsDNA/DOX and the cells were moved into a well of a 96-well plate and cultured for $24 \mathrm{~h}$. Then, the $100 \mu \mathrm{L}$ of the medium was removed, and $10 \mu \mathrm{L}$ of $5 \mathrm{mg} / \mathrm{mL}$ MTT was added for another $4 \mathrm{~h}$ of incubation. Then, all the solutions were removed and replaced with $100 \mu \mathrm{L}$ DMSO solution. The cells were quantified using an ELISA plate reader at a wavelength of $570 \mathrm{~nm}$.

\subsection{Target Molecule Delivery under HFMF}

HeLa and MCF-7 cells were cultured in DMEM supplemented with $10 \%$ fetal bovine serum and $1 \%$ penicillin-streptomycin. Then, the cells were incubated in humidified air containing a $5 \% \mathrm{CO}_{2}$ atmosphere at $37^{\circ} \mathrm{C}$ and changed every $2.5 \mathrm{~d}$. After being detached with trypsin, 90,000 cells were plated in each well of a 6-well plate with a total of $3 \mathrm{~mL}$ DMEM (0.1 mg/mL Fe $\mathrm{O}_{4} @ \mathrm{Au}$ NPs-dsDNA/DOX) supplemented with $10 \%$ fetal bovine serum and $1 \%$ penicillin-streptomycin and then placed in an incubator for another $24 \mathrm{~h}$. 
The medium was changed to DMEM supplemented with $1 \%$ penicillin-streptomycin with no fetal bovine serum. After incubation for $24 \mathrm{~h}, 2 \mathrm{~mL}$ of the medium with the different sized $\mathrm{Fe}_{3} \mathrm{O}_{4} @ \mathrm{Au}$ NPs-dsDNA/DOX were substituted for the original medium. Before washing with PBS buffer, all plates were placed in an incubator for $4 \mathrm{~h}$ for targeting. After cells were subcultured from each other and treated with HFMF, the cells were seeded into 96-well plates at 500 cells per well and further cultured for one day. To determine cell viability, the MTT assay was directly performed.

\section{Results and Discussion}

\subsection{Synthesis and Characterization of $\mathrm{Fe}_{3} \mathrm{O}_{4} @ A u \mathrm{NPs}$}

The $\mathrm{Fe}_{3} \mathrm{O}_{4}$ NPs were successfully synthesized by the coprecipitation method and can be well dispersed in an aqueous solution of TMAOH. In contrast to poor dispersion in deionized water (see Figure 1a), the TMAOH is a proper surfactant for stability and better solution dispersion. Figure $1 \mathrm{~b}$ shows that the size of the $\mathrm{Fe}_{3} \mathrm{O}_{4} \mathrm{NPs}$ is approximately $10 \mathrm{~nm}$. Subsequently, the $\mathrm{Fe}_{3} \mathrm{O}_{4}$ NPs were covered with an $\mathrm{Au}$ shell by reducing $\mathrm{HAuCl}_{4}$ with sodium citrate. Scanning electron microscopy images (Figure 1a (right) and Figure 1c) were taken to calculate the size distribution (Image-Pro Plus, MD, USA), and the average sizes of the $\mathrm{Fe}_{3} \mathrm{O}_{4}$ and $\mathrm{Fe}_{3} \mathrm{O}_{4} @ \mathrm{Au}$ NPs were $9.6 \pm 3.0 \mathrm{~nm}$ and $39.5 \pm 3.0 \mathrm{~nm}$, respectively (Figure 1g,h). Figure 1d shows that the NPs exhibited a core-shell morphology. And the NPs showed an average size of $40 \mathrm{~nm}$ without any aggregation, which corresponded to the aforementioned SEM image (Figure 1c). The selected area electron diffraction (SAED) patterns were also used to study the core-shell structure of the NPs. According to the SAED patterns, $\mathrm{Fe}_{3} \mathrm{O}_{4}$ NPs can be indexed as $\mathrm{Fe}_{3} \mathrm{O}_{4}$ (JCPD 89-6446) corresponding to (200), (230), and (133); the $\mathrm{Fe}_{3} \mathrm{O}_{4} @ \mathrm{Au} \mathrm{NPs}$ can be indexed as $\mathrm{Fe}_{3} \mathrm{O}_{4}$ (JCPD 89-6446) corresponding to (122) and (006), and the (311) and (220) planes were referred to Au (JCPD 89-3697 and 65-2870) (Figure 1e). Due to the SPR of the Au shell, UV-Vis spectroscopy was used to confirm the existence of the Au shell. A strong absorbance peak at $530 \mathrm{~nm}$ in the $\mathrm{Fe}_{3} \mathrm{O}_{4} @ \mathrm{Au}$ NPs was absent in the spectrum of pure $\mathrm{Fe}_{3} \mathrm{O}_{4}$ NPs (Figure 1f).

To discuss the influence of different $\mathrm{Fe}_{3} \mathrm{O}_{4} @ \mathrm{Au}$ NP sizes, the SEM images and size distribution calculated by Image Pro-Plus (IPP) software were studied at different reactant concentrations (Figure 2). According to the SEM images, the size distribution of the $\mathrm{Fe}_{3} \mathrm{O}_{4} @ \mathrm{Au}$ NPs exhibited mean diameters of $59.5 \pm 10.5 \mathrm{~nm}, 47.7 \pm 7.1 \mathrm{~nm}, 39.5 \pm 5.7 \mathrm{~nm}$, $33.1 \pm 5.0 \mathrm{~nm}$, and $25.9 \pm 6.0 \mathrm{~nm}$. According to the average size of $\mathrm{Fe}_{3} \mathrm{O}_{4} @ \mathrm{Au} \mathrm{NPs}$, the gold nano-shell sizes distribution was shown: $49.9 \pm 7.5 \mathrm{~nm}, 38.1 \pm 4.1 \mathrm{~nm}, 29.9 \pm 2.7 \mathrm{~nm}$, $23.5 \pm 2.0 \mathrm{~nm}$, and $16.3 \pm 3.0 \mathrm{~nm}$, respectively. Since the size distribution of NPs has a large impact on the absorbance peak caused by the surface plasma resonance effect, the absorbance peak at approximately $530 \mathrm{~nm}$ was shown to be the characteristic peak of the $\mathrm{Au}$ NPs (Figure 3a). For different $\mathrm{Fe}_{3} \mathrm{O}_{4} @ \mathrm{Au}$ NP sizes, the inset Figure shows that the absorbance peaks of larger NPs had a greater redshift than those of smaller NPs, which shows that the Au NP size was closely related to their optical characteristics. The particle sizes decreased from 59.5 to $25.9 \mathrm{~nm}$, and absorbance peaks could be observed at 535, $532,530,528$, and $525 \mathrm{~nm}$. The crystalline structure of the $\mathrm{Fe}_{3} \mathrm{O}_{4} @ \mathrm{Au} \mathrm{NPs}$ of different sizes was characterized by XRD (Figure $3 b$ ). The diffraction peaks of the $\mathrm{Fe}_{3} \mathrm{O}_{4} @ \mathrm{Au} \mathrm{NPs}$ are indicated at $38.2^{\circ}, 44.4^{\circ}, 64.6^{\circ}$, and $77.6^{\circ}$, which can be indexed to the (111), (200), (220), and (311) planes of Au in a cubic phase with a JCPD code of 65-2870. Furthermore, the intensity of the (311) plane of the $\mathrm{Fe}_{3} \mathrm{O}_{4}$ NPs decreased as the thickness of the $\mathrm{Au}$ nano-shell increased. In addition, the increase in each Au diffraction peak with increasing particle size confirmed that the composition of the $\mathrm{Au}$ increased and presented that the $\mathrm{Fe}_{3} \mathrm{O}_{4}$ NPs were fully covered with $\mathrm{Au}$ nano-shells without $\mathrm{Fe}_{3} \mathrm{O}_{4}$ NPs. The magnetic properties of the $\mathrm{Fe}_{3} \mathrm{O}_{4} @ \mathrm{Au}$ NPs were investigated by SQUID (at $25{ }^{\circ} \mathrm{C}$ with the magnetic field sweeping from $-18,000$ to $+18,000 \mathrm{G})$. As shown in Figure $3 \mathrm{c}$, all curves for the $\mathrm{Fe}_{3} \mathrm{O}_{4}$ NPs and $\mathrm{Fe}_{3} \mathrm{O}_{4} @ \mathrm{Au}$ NPs had similar shapes with negligible hysteresis, signifying superparamagnetic properties. The saturation magnetization (Ms) of the $\mathrm{Fe}_{3} \mathrm{O}_{4} \mathrm{NPs}_{\text {was }}$ $25 \mathrm{emu} / \mathrm{g}$, and the value decreased gradually with increasing Au nano-shell thickness. 
The relation between the Au nano-shell thickness and the saturation magnetization value (Figure 3d) was quantified. The linear relation between the ratio of $\mathrm{Fe}_{3} \mathrm{O}_{4} \mathrm{NPs} \mathrm{Ho}_{3} \mathrm{O}_{4} @ \mathrm{Au}$ NPs and the saturation magnetization value is $y=6.02 x+0.6$ with a correlation coefficient of 0.98 . The Au nano-shell in this study provided an increasing shielding effect for the $\mathrm{Fe}_{3} \mathrm{O}_{4} \mathrm{NPs}$ as the thickness of the Au nano-shell increased.
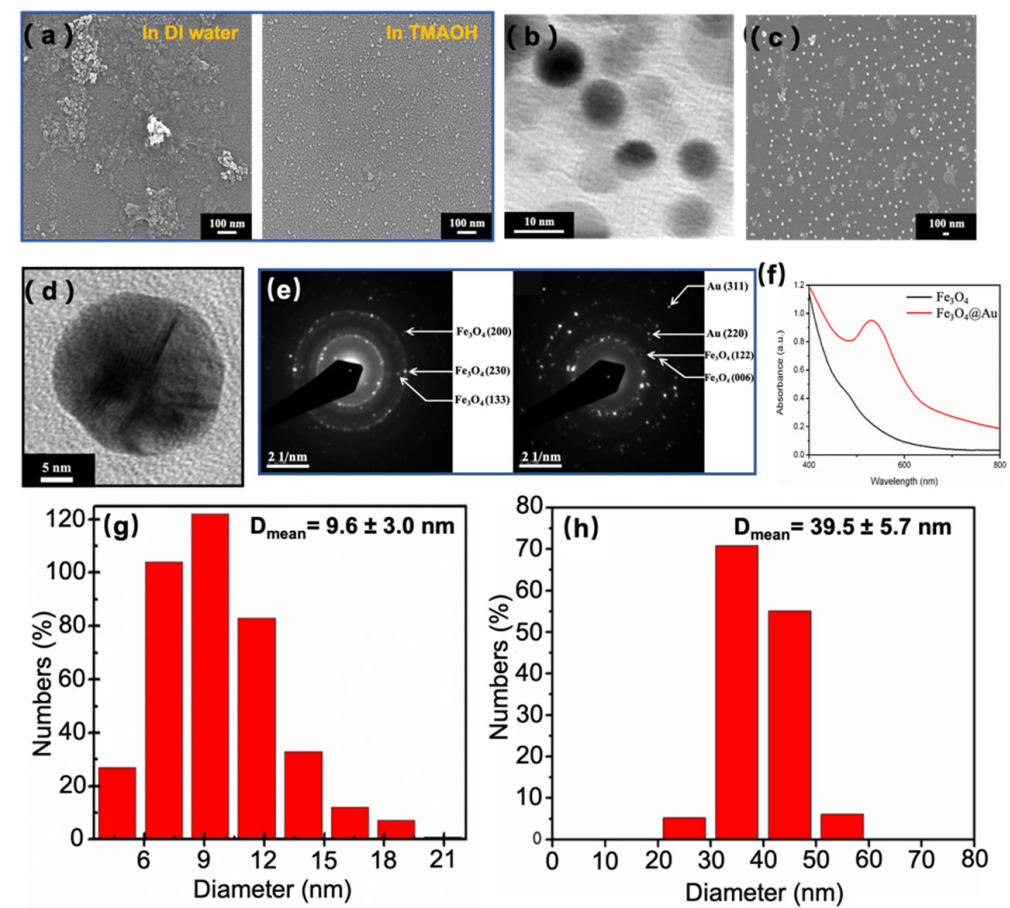

Figure 1. SEM images of the $\mathrm{Fe}_{3} \mathrm{O}_{4}$ NPs: (a) in DI water (left) and 0.1 M TMAOH (right). (b) TEM images of the $\mathrm{Fe}_{3} \mathrm{O}_{4}$ NPs. (c) SEM image of the $\mathrm{Fe}_{3} \mathrm{O}_{4} @ \mathrm{Au}$ NPs. (d) TEM image of the $\mathrm{Fe}_{3} \mathrm{O}_{4}$ NP-processed coating Au nano-shell. (e) SAED patterns of the $\mathrm{Fe}_{3} \mathrm{O}_{4}$ NPs and $\mathrm{Fe}_{3} \mathrm{O}_{4} @ A$ Au NPs. (f) UV-Vis spectrum of the $\mathrm{Fe}_{3} \mathrm{O}_{4} \mathrm{NPs}$ and $\mathrm{Fe}_{3} \mathrm{O}_{4} @ A u$ NPs. (g) Size distribution of the $\mathrm{Fe}_{3} \mathrm{O}_{4} \mathrm{NPs}$ and (h) the corresponding size distribution of the $\mathrm{Fe}_{3} \mathrm{O}_{4} @ \mathrm{Au} \mathrm{NPs}$.
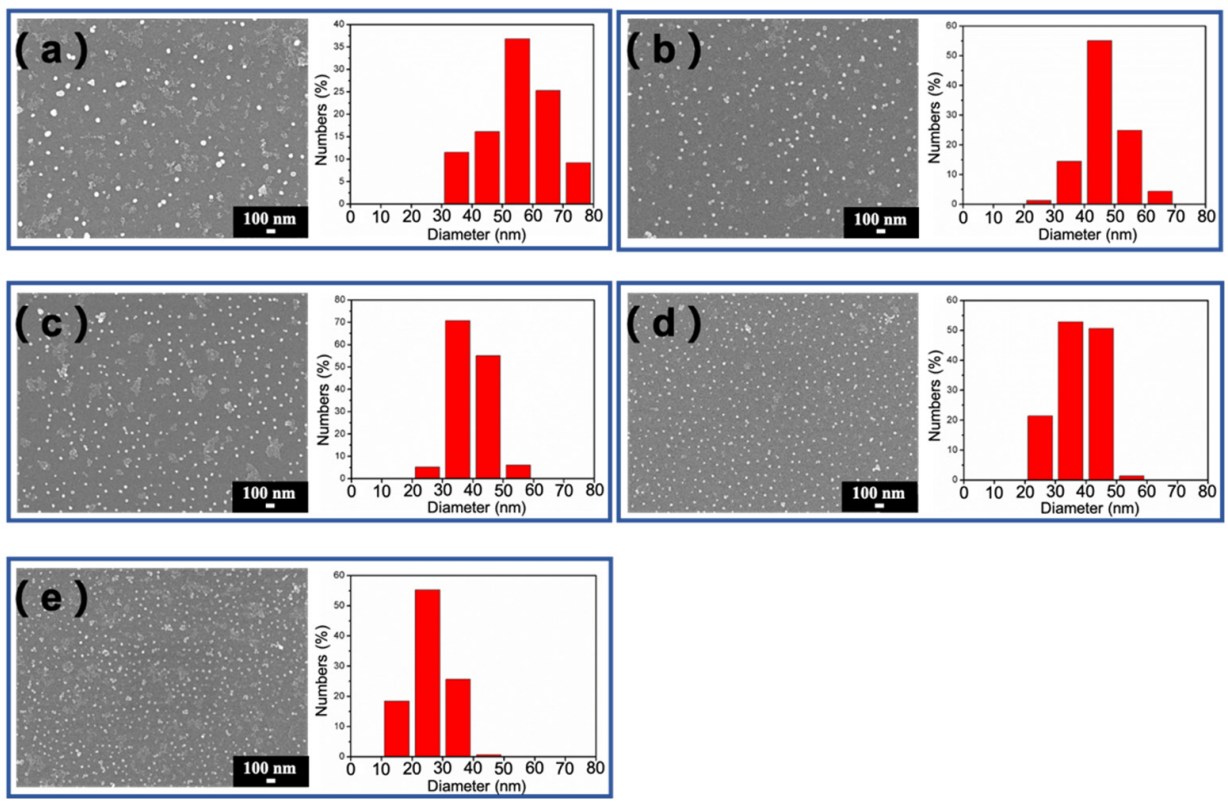

Figure 2. (a-e) SEM images of different $\mathrm{Fe}_{3} \mathrm{O}_{4} @ \mathrm{Au} \mathrm{NP}$ sizes and their corresponding size distribution (mean diameters of $59.5 \pm 10.5 \mathrm{~nm}, 47.7 \pm 7.1 \mathrm{~nm}, 39.5 \pm 5.7 \mathrm{~nm}, 33.1 \pm 5.0 \mathrm{~nm}$, and $26.0 \pm 6.0 \mathrm{~nm}$ ). 

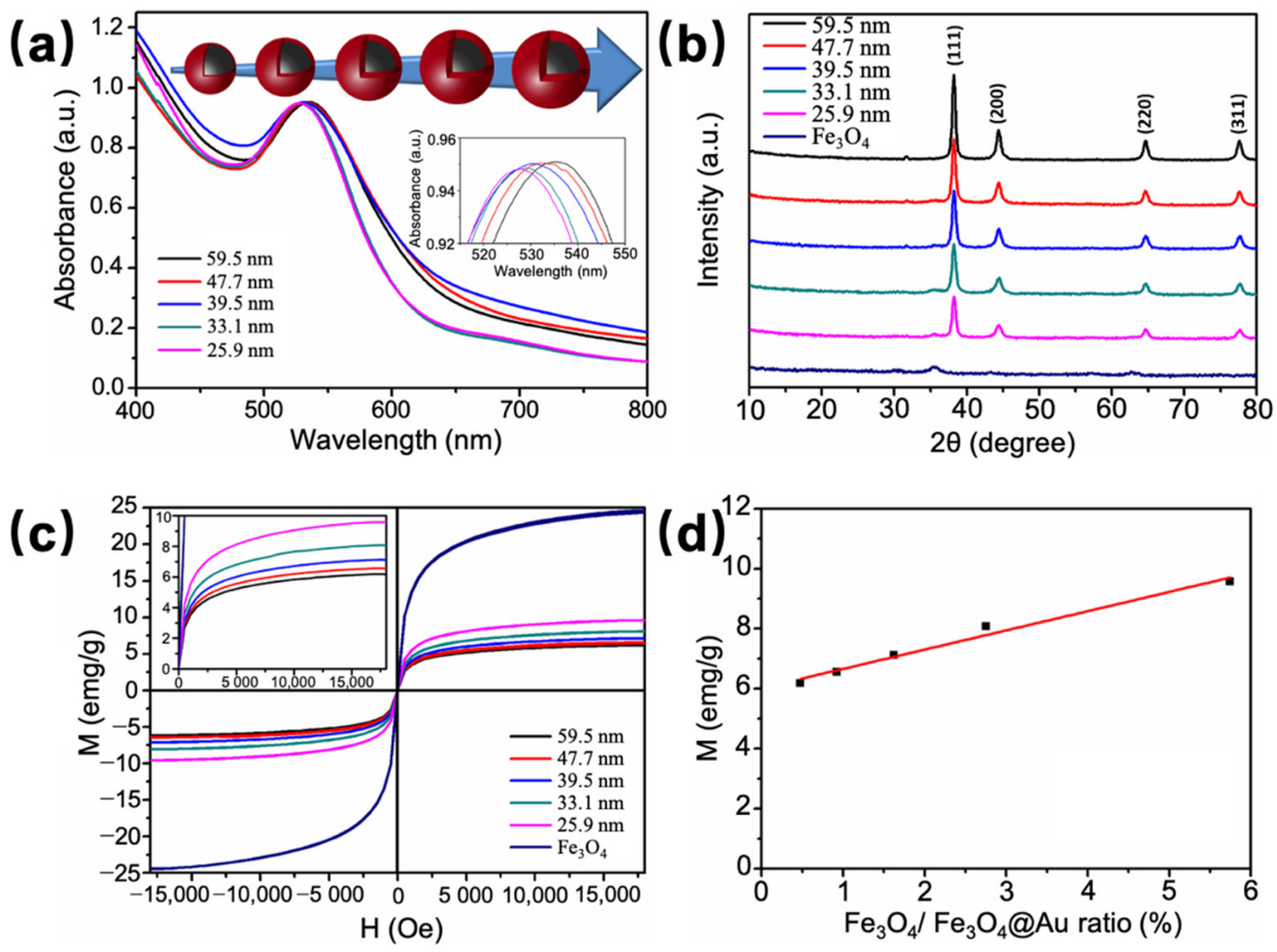

Figure 3. (a) UV-Vis spectra of different $\mathrm{Fe}_{3} \mathrm{O}_{4} @ \mathrm{Au} \mathrm{NP}$ sizes, the inset shows the difference of absorbance peak among each size of nanoparticles. (b) XRD patterns of different $\mathrm{Fe}_{3} \mathrm{O}_{4} @ \mathrm{Au}$ NPs and $\mathrm{Fe}_{3} \mathrm{O}_{4}$ NPs size distributions. (c) Magnetic hysteresis loops for the $\mathrm{Fe}_{3} \mathrm{O}_{4} \mathrm{NPs}$ and different $\mathrm{Fe}_{3} \mathrm{O}_{4} @ \mathrm{Au}$ NP sizes. (d) The linear relationship between the saturation magnetization and the $\mathrm{Fe}_{3} \mathrm{O}_{4}$ NP constitution ratio.

\subsection{Quantitative Analysis on Molecule Loading and Sensing Capacity}

The nanocarriers were fabricated by $\mathrm{Fe}_{3} \mathrm{O}_{4} @ \mathrm{Au}$ NPs-dsDNA/DOX, to quantify the anticancer effect of DOX, the detection limits (LODs) calculation towards DOX was performed through standard deviation and linear fittings and DOX calibration curves of $(y=528.19 x+0.35)$ were obtained for the PL spectrum (Figure S1a). A previous study indicated that DOX intercalated prior into consecutive CG base pairs; as a consequence, the related oligonucleotide $\mathrm{C}(\mathrm{GA})_{6}$, which enhanced the DOX-loading capacity, provided binding sites for a minimum of 6 DOX molecules. Since the fluorescence of DOX was quenched when intercalated into oligonucleotides, the calibration curve $(y=9951.28-$ $1367.19 x \times \ln (x+4.72))$ was defined as the ability to bind DOX with DNA (Figure S1b). The nonlinear relation between the remaining DOX intensity and the concentration of DNA, which also illustrated the nonlinear quenching ability of DNA, is also used to calculate the binding constant of the drug-DNA complex [43]. It is also important to provide the number of DOX molecules bound by each single DNA strand by plotting the fluorescence intensity $\left(\log \left[\left(\mathrm{F}_{0}-\mathrm{F}\right) / \mathrm{F}\right]\right)$ and various concentrations of DNA $(\log [\mathrm{DNA}])$ (Figure S1c). The results showed a slope value of 0.9 , which indicates that 0.9 DOX molecules were bound by each single DNA strand, and the binding constant $(\mathrm{K})$ of DOX molecules and DNA was 0.026 . This curve was also used to further calculate the concentration of DNA binding on various $\mathrm{Fe}_{3} \mathrm{O}_{4} @ \mathrm{Au}$ NP sizes. To further identify the concentration of DOX that had intercalated into oligonucleotides, the remaining concentration minus the original concentration was defined as the different NP sizes (26.0, 33.1, 39.5, 47.7, and $59.5 \mathrm{~nm})$ intercalated with 4.6, 4.0, 3.6, 3.9, and 4.3 $\mu \mathrm{M}$ DOX. The concentrations of DNA that bound to different NP sizes were $379.8,309.9,274.0,304.0$, and $346.6 \mathrm{nM}$, respectively, because of the electrostatic force between the $\mathrm{Fe}_{3} \mathrm{O}_{4} @ \mathrm{Au} \mathrm{NP}$ and DNA. Furthermore, the zeta potential was applied to confirm the DNA sequences and intercalation of DOX. Table 2 
suggests that the zeta potential decreased with increasing $\mathrm{Fe}_{3} \mathrm{O}_{4} @ \mathrm{Au} \mathrm{NP}$ diameter. After conjugation with DNA, the zeta potential slightly increased due to the negative charge of the DNA molecules [44], and a greater DNA binding concentration resulted in a greater zeta potential value. In addition, intercalated DOX caused a dramatic reduction due to the interaction between the opposite charges of DOX and DNA molecules [45]. We speculated that the surface area may strongly influence the oligonucleotide binding concentration. Figure $4 \mathrm{a}, \mathrm{b}$ shows the relationship between the DNA and DOX concentration and the $\mathrm{Fe}_{3} \mathrm{O}_{4} @ \mathrm{Au} \mathrm{NP}$ surface area. These results could not be represented by the trend line due to the difference of particle numbers between each size of $\mathrm{Fe}_{3} \mathrm{O}_{4} @ \mathrm{Au}$ NPs. After excluding the effect of particle number, the binding concentration of oligonucleotide per particle linearly correlate with the oligonucleotide binding concentration per particle surface area, the linear relation is $y=4.34 \times 10^{-14} x-2.43 \times 10^{-10}\left(R^{2}=0.98\right)$ and $y=5.43 \times 10^{-16} x-$ $2.89 \times 10^{-12}\left(R^{2}=0.99\right)$, respectively (Figure $\left.4 \mathrm{c}, \mathrm{d}\right)$. Our result suggests that the surface area is a crucial factor that influences the oligonucleotide binding concentration and the DOX molecule loading capability.

Table 2. Zeta potential of different $\mathrm{Fe}_{3} \mathrm{O}_{4} @ \mathrm{Au} \mathrm{NP}, \mathrm{Fe}_{3} \mathrm{O}_{4} @ \mathrm{Au}$ NP-dsDNA, and $\mathrm{Fe}_{3} \mathrm{O}_{4} @ \mathrm{Au}$ NPdsDNA/DOX sizes.

\begin{tabular}{cccc}
\hline & \multicolumn{3}{c}{ Zeta Potential $(\mathbf{m V})$} \\
\hline Diameter $(\mathbf{n m})$ & $\mathrm{Fe}_{\mathbf{3}} \mathbf{O}_{\mathbf{4}} @ \mathbf{A u}$ & $\mathrm{Fe}_{3} \mathbf{O}_{\mathbf{4}} @ \mathbf{A u}$-dsDNA & $\mathbf{F e}_{3} \mathbf{O}_{\mathbf{4}} @$ @Au-dsDNA/DOX \\
\hline 25.9 & -44.3 & -49.3 & -26.0 \\
33.1 & -40.2 & -45.4 & -29.5 \\
39.5 & -37.4 & -39.4 & -33.1 \\
47.7 & -36.7 & -40.5 & -30.7 \\
59.5 & -36.5 & -46.0 & -29.0 \\
\hline
\end{tabular}

(a)

\section{(c)}

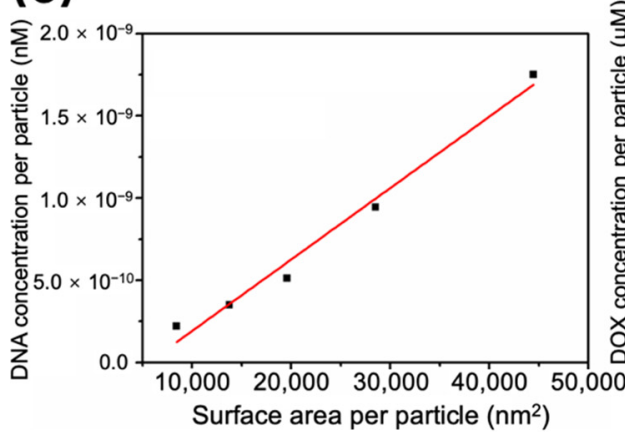

(b)

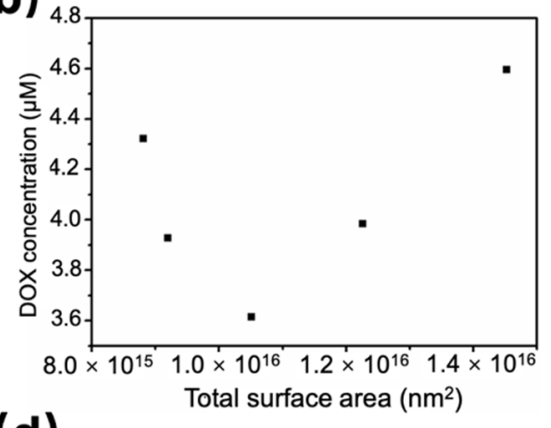

(d)

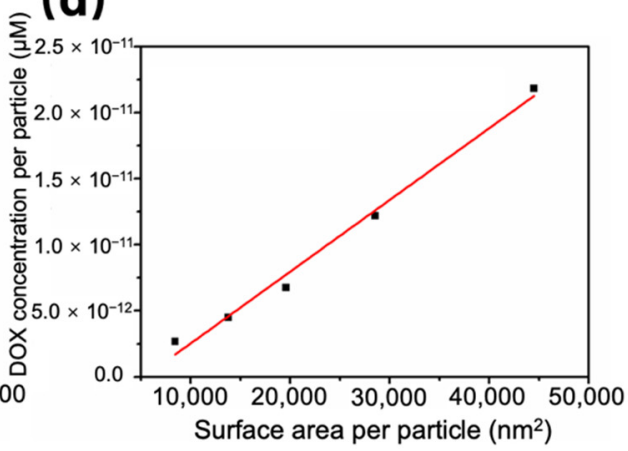

Figure 4. Relationship between the total surface area and (a) the DNA binding concentrations and (b) the DOX intercalating concentration. Relationship between the surface area per particle and (c) the DNA binding concentration per particle and $(\mathbf{d})$ the DOX intercalating concentration per particle. 


\subsection{Capabilities of the Multifunctional Molecule Delivery System}

HFMF was used to induce hyperthermia, which is a therapy for cancer cells with heat generated by magnetic NPs under a strong oscillating magnetic field. After a slight temperature increase (at approximately $40{ }^{\circ} \mathrm{C}$ ), a series of subcellular events are initiated and give rise to the cells susceptible to diverse damage, resulting in subsequent cell death. Moreover, increasing the temperature can also increase the thermosensitivity of cancer cells, which helps improve the efficiency of chemotherapy [46,47]. It is obvious that the $\mathrm{Fe}_{3} \mathrm{O}_{4} @ \mathrm{Au}$ NPs with thinner Au nano-shells lead to a more conspicuous temperature rise, and the solution temperature attains $39.8{ }^{\circ} \mathrm{C}$ at a $\mathrm{Fe}_{3} \mathrm{O}_{4} @ \mathrm{Au} \mathrm{NP}$ diameter of $25.9 \mathrm{~nm}$ after a magnetic field is applied for $20 \mathrm{~min}$ (Figure 5a). By contrast, the largest $\mathrm{Fe}_{3} \mathrm{O}_{4} @ \mathrm{Au} \mathrm{NPs}$ (diameter of $59.5 \mathrm{~nm}$ ) increased to $38.4{ }^{\circ} \mathrm{C}$ under the same experimental conditions. The specific loss power (SLP) was used to represent the ability of thermogenesis of the NPs from the magnetic coupling between the magnetic moment of the NPs and the utilized HFMF and was defined as the thermal power dissipation divided by the mass of magnetic NPs. The value of the SLP was applied to more accurately represent the ability of the NPs to be used in hyperthermia applications and was calculated by Equation (1), where $\Delta \mathrm{T}$ is the vibrational temperature, $\Delta \mathrm{t}$ is the period of time, $\mathrm{mf}$ is the weight of magnetic NPs, $\mathrm{C}_{\mathrm{f}}$ is the heat capacity of $\mathrm{Fe}_{3} \mathrm{O}_{4} \mathrm{NPs}$, $\mathrm{mw}$ is the weight of the solution (deionized water), and $C_{W}$ is the heat capacity of water [48]. As shown in Table 3, the SLP value decreased from 148.95 to $91.24 \mathrm{w} / \mathrm{g}$ when the diameter of the $\mathrm{Fe}_{3} \mathrm{O}_{4} @ \mathrm{Au}$ NPs increased from 25.92 to $59.50 \mathrm{~nm}$. The results indicate that a thicker Au shell causes a lower magnetically induced heating ability.

$$
\mathrm{SLP}=\frac{\Delta \mathrm{T}}{\Delta \mathrm{t}} \times \frac{\mathrm{m}_{\mathrm{f}} \mathrm{C}_{\mathrm{f}}+\mathrm{m}_{\mathrm{w}} \mathrm{C}_{\mathrm{w}}}{\mathrm{m}_{\mathrm{f}}}
$$

Table 3. SLP values of various $\mathrm{Fe}_{3} \mathrm{O}_{4} @ \mathrm{Au}$ NP sizes.

\begin{tabular}{cc}
\hline Diameter $(\mathbf{n m})$ & SLP Value $(\mathbf{W} / \mathbf{g})$ \\
\hline 25.9 & 149.0 \\
33.1 & 127.4 \\
39.5 & 120.3 \\
47.7 & 112.5 \\
59.5 & 91.2 \\
\hline
\end{tabular}

To further understand the stability of the molecule delivery system, the release percentage was measured at $37^{\circ} \mathrm{C}$ (in physiological conditions). The plot of release percentage $(\%)$ in $70 \mathrm{~h}$ versus the diameter of the $\mathrm{Fe}_{3} \mathrm{O}_{4} @ \mathrm{Au}$ NPs showed the same maximum release percentage of approximately $30-40 \%$ for each $\mathrm{Fe}_{3} \mathrm{O}_{4} @ \mathrm{Au}$ NP size. This percentage is acceptable stability for DOX molecule delivery (Figure $5 b$ ). The release percentage showed a significant decrease after $24 \mathrm{~h}$, which may be caused by a decrease in the fluorescence after a long period of time or the re-intercalation of DOX into oligonucleotides. In contrast, as a result of the heat produced by $\mathrm{Fe}_{3} \mathrm{O}_{4} @ \mathrm{Au}$ NPs under HFMF, DOX that had intercalated in oligonucleotides could be released. With increasing time (from 0 to $20 \mathrm{~min}$ ), the release percentage increased to $60-80 \%$ for different $\mathrm{Fe}_{3} \mathrm{O}_{4} @ \mathrm{Au}$ NP diameters (from 25.9 to $59.5 \mathrm{~nm}$ ) at $37^{\circ} \mathrm{C}$ (Figure $5 \mathrm{c}$ ), the increase rate was clearly slower than the first $7 \mathrm{~min}$, as the reason for the applying time of HFMF. To further illustrate the relationship between the particle size and the DOX molecule release ability, the DOX concentration released per particle $(\mu \mathrm{M})$ was plotted as a function of the DOX concentration carried per particle $(\mu \mathrm{M})$ (Figure S2): a linear relation between the released and carried concentration $(y=0.7691 x-$ $\left.8.2156, R^{2}=0.99\right)$ was found. 

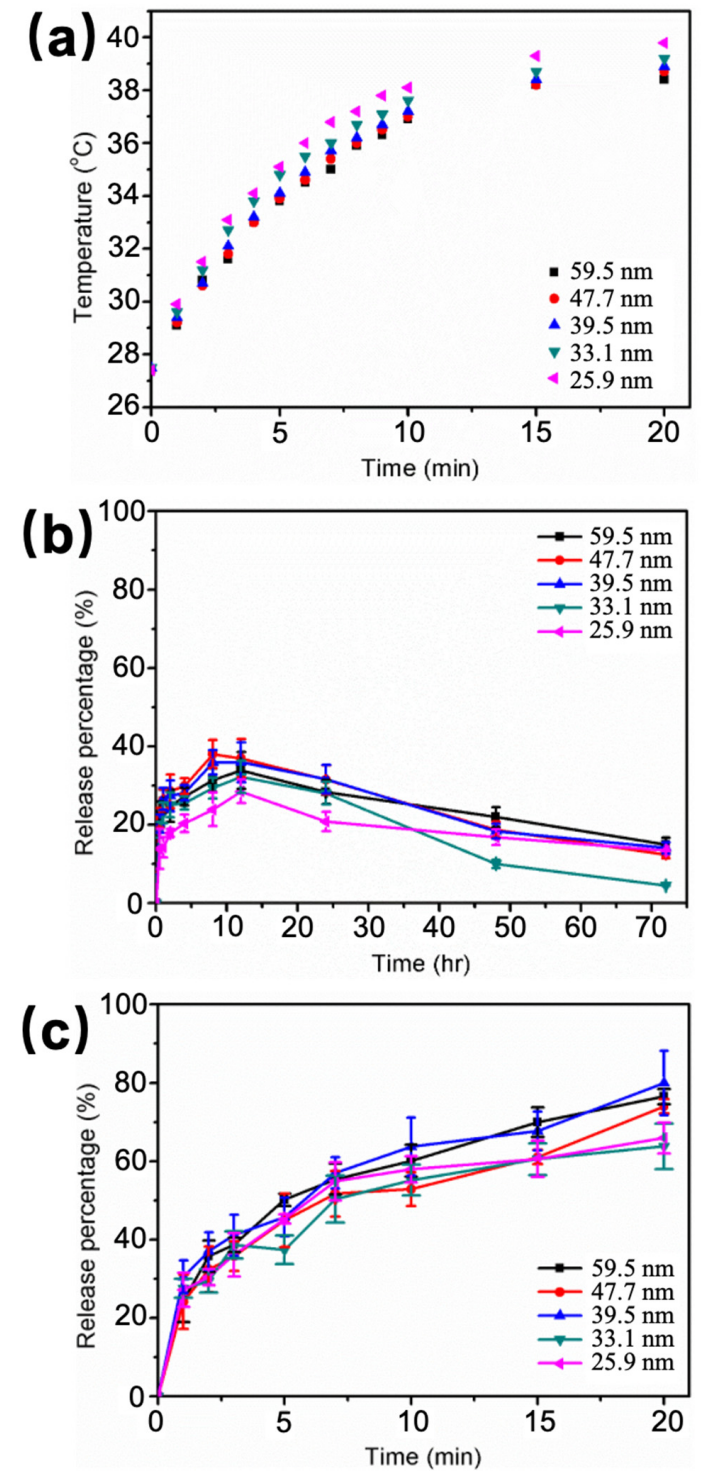

Figure 5. (a) Size effect on the temperature increase after applying HFMF for different periods of time. (b) Size effect on the DOX release profile from DOX-loaded $\mathrm{Fe}_{3} \mathrm{O}_{4} @ A$ ANPs-dsDNA by diffusion at $37^{\circ} \mathrm{C}$. (c) Size effect on DOX release ability when applying HFMF.

\subsection{Application of Release Actuator for Treatment}

We then investigated the integrative ability as a multifunctional DOX molecule delivery system using an in vitro test. In this study, the cytotoxicity of our system was the main concern before further applications. The MTT assay was performed to test the targeting ability of the molecule delivery system through the observation of the absorbance to assess the number of cells that survive. Two different cell lines (HeLa and MCF-7) have been used to compare the cell viability. Especially, the MCF-7 was chosen as a targeted cell due to its specific binding ability with the aptamer, which the HeLa cells do not have. We selected the HeLa cell line as a host cell to investigate the cytotoxicity of different $\mathrm{Fe}_{3} \mathrm{O}_{4} @ \mathrm{Au} \mathrm{NP}$ sizes and $\mathrm{Fe}_{3} \mathrm{O}_{4} @ \mathrm{Au}$ NPs-dsDNA with $\mathrm{Fe}_{3} \mathrm{O}_{4} @ \mathrm{Au}$ NPs-dsDNA/DOX as a negative control group. Among these three systems, the $\mathrm{Fe}_{3} \mathrm{O}_{4} @ \mathrm{Au} \mathrm{NPs}$ were covered with Tween 20 as a protective agent to prevent the aggregation of NPs when suspended in a culture medium. Since the dsDNA conjugated on the surface of the $\mathrm{Fe}_{3} \mathrm{O}_{4} @ \mathrm{Au} \mathrm{NPs}$ could also be applied as a protection agent, these two systems were examined without adding Tween 20. After incubation with HeLa cells with differently sized NP systems for $24 \mathrm{~h}$, the cell viability remained approximately $100 \%$ or even higher after incubation with 
$\mathrm{Fe}_{3} \mathrm{O}_{4} @ \mathrm{Au}$ NPs (Figure 6a). $\mathrm{Fe}_{3} \mathrm{O}_{4} @ \mathrm{Au}$ NP-dsDNA, with a particle size of $39.5 \mathrm{~nm}$, showed the lowest cell viability. Compared with a particle size of $25.9 \mathrm{~nm}$, which was the largest, the viability showed a similar trend as the DNA binding concentration, which indicates that the DNA binding concentration could have a great influence on cell viability. Since DNA is a biocompatible molecule, it could offer lower cytotoxicity for our system; nevertheless, even though the cell viability showed different values for each NP size, the lowest cell viability was still greater than $90 \%$. In addition, DOX-loaded $\mathrm{Fe}_{3} \mathrm{O}_{4} @ \mathrm{Au}$ NPs-dsDNA showed lower cell viability for each size compared to $\mathrm{Fe}_{3} \mathrm{O}_{4} @ \mathrm{Au}$ NPs-dsDNA without DOX molecule loading, and the results were caused by the diffusive release of DOX from the substrate. This can be further confirmed by the $\mathrm{Fe}_{3} \mathrm{O}_{4} @ \mathrm{Au}$ NPs-dsDNA with a particle size of $39.5 \mathrm{~nm}$ having the lowest DOX loading concentration and the greatest cell viability among other particle sizes. The ability as a cancer therapy agent was examined by mixing HeLa cells with different of $\mathrm{Fe}_{3} \mathrm{O}_{4} @ \mathrm{Au}$ NPs-dsDNA/DOX sizes and applying HFMF for $7 \mathrm{~min}$. After the magnetic field treatment, the cells were further incubated for $12 \mathrm{~h}$ for proper attachment before the MTT assay. Importantly, compared to the control group, the cell viability of the DOX-loaded $\mathrm{Fe}_{3} \mathrm{O}_{4} @ \mathrm{Au} \mathrm{NP}$-dsDNA group was significantly lower, showing that our system has the good capability as a cancer agent. For pure DOX, $8.6 \mu \mathrm{M}$ caused approximately 75\% endocytosis, whereas $\mathrm{Fe}_{3} \mathrm{O}_{4} @ \mathrm{Au}$ NPs-dsDNA/DOX achieved the same effect with only $2 \mu \mathrm{M}$ DOX release.
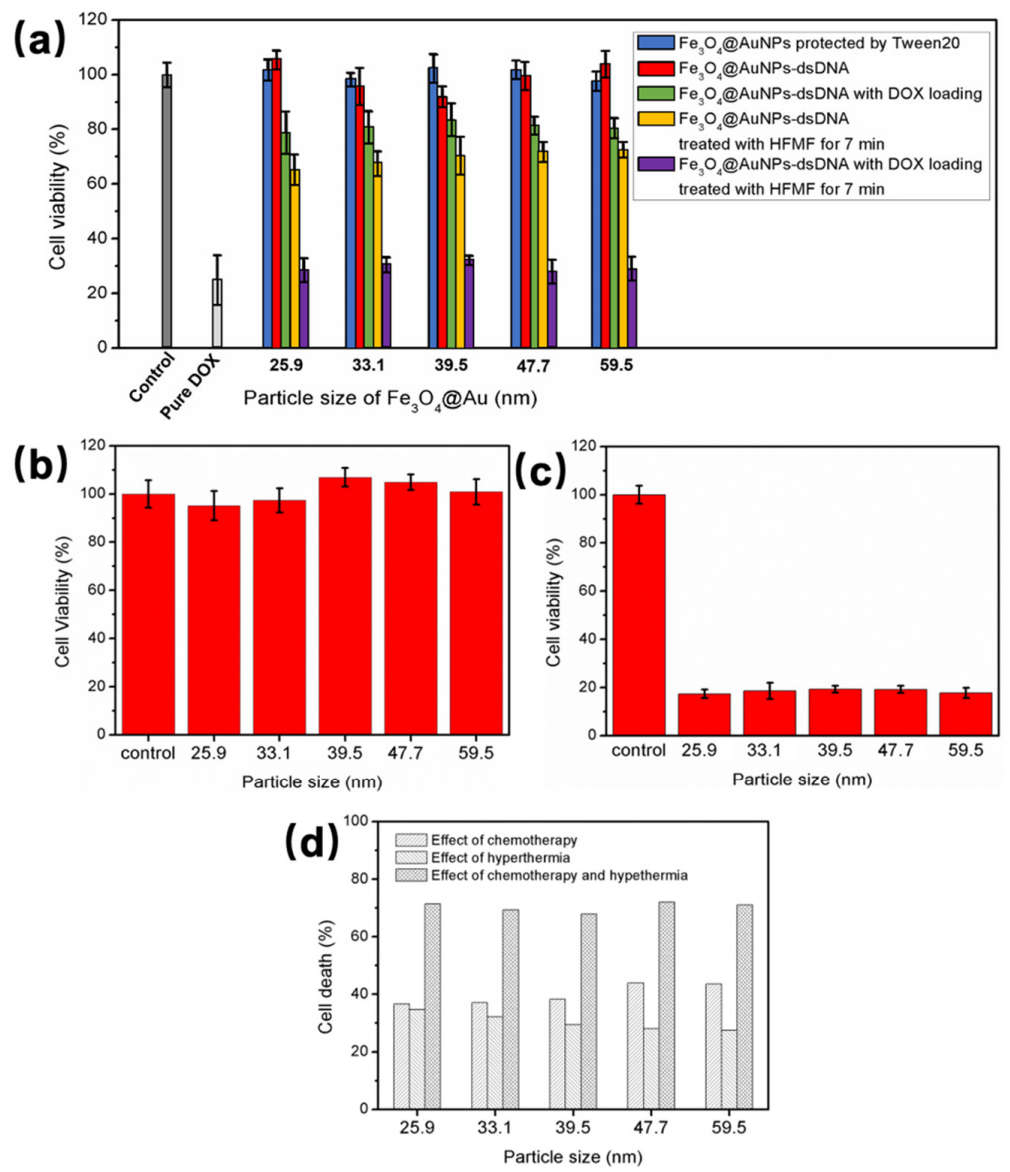

Figure 6. (a) HeLa cell viability after being treated with differently sized $\mathrm{Fe}_{3} \mathrm{O}_{4} @ \mathrm{Au} \mathrm{NPs}, \mathrm{Fe}_{3} \mathrm{O}_{4} @ \mathrm{Au}$ NPs conjugated with dsDNA, $\mathrm{Fe}_{3} \mathrm{O}_{4} @ \mathrm{Au}$ NPs-dsDNA loaded with DOX, $\mathrm{Fe}_{3} \mathrm{O}_{4} @ \mathrm{Au}$ NPs-dsDNA after treatment with $\mathrm{HFMF}$, and $\mathrm{Fe}_{3} \mathrm{O}_{4} @ \mathrm{Au}$ NPs-dsDNA loaded with DOX after treatment with HFMF. Cell viability of $\mathrm{Fe}_{3} \mathrm{O}_{4} @ \mathrm{Au}$ NPs-dsDNA/DOX after targeting with aptamer and washing with PBS for (b) HeLa cells and (c) MCF-7 cells. (d) Effects of hyperthermia and chemotherapy on MCF-7 cells. 
Except for lower DOX concentration, targeting the carrier to a specific cell is an efficient way to decrease side effects, and MCF-7, a targeted cell, was employed in this study. An aptamer sequence that had been demonstrated to have a specific binding ability with MCF-7 breast cancer cells was chosen [49], and HeLa cells were used as the control group, nanoparticles could be easily washed off by PBS. There was a notable distinction between the HeLa and MCF-7 cells after HFMF treatment; for the HeLa cells, cell viability remained greater than 95\% among all DOX molecule carriers $\left(\mathrm{Fe}_{3} \mathrm{O}_{4} @ \mathrm{Au}\right.$ NPs-dsDNA/DOX) of different sizes (Figure 6b). In contrast, the cell viability for MCF-7 cells decreased due to the effects of hyperthermia and chemotherapy (Figure 6c,d). Moreover, the IC50 was also texted based on these two cell lines (Table S1). The best particle size for future applications is about $25.95 \mathrm{~nm}$ to maintain a greater hyperthermia effect, and a lower DOX molecule concentration could be achieved by using our designed carriers.

\section{Conclusions}

In summary, we developed a multifunctional $\mathrm{Fe}_{3} \mathrm{O}_{4} @ \mathrm{Au} \mathrm{NP}$ material as the molecule delivery system. Various size distribution of NPs conjugated with specific DNA sequence can load various amounts of DOX (as the anticancer) molecules. Due to the difference in the surface area, particle number, and steric hindrance effect, the number of DNA sequences bound varied with the core-shell nanoparticle size. DOX molecules can be controllably released from hyperthermia effect by means of HFMF triggering. The Au nano-shell caused a shielding effect on magnetic effect, which led to different SLP values and resulted in a $30-40 \%$ greater release than diffusion when applying HFMF for $20 \mathrm{~min}$ in a moleculecarrier system. The cytotoxicity and cancer treatment capability were examined using an in vitro cell viability test and showed lower cytotoxicity with higher DNA binding concentrations. However, the cell survival ratio decreased to $80 \%$ due to diffusion release from the molecule-loaded carriers. The application of HFMF resulted in the lowest dosage and could further decrease the side effects of both chemotherapy and hyperthermia. $\mathrm{Fe}_{3} \mathrm{O}_{4} @ \mathrm{Au}$ core-shell NPs may be regarded as a multifunctional nanocarrier for the future theranostics of cancer.

Supplementary Materials: The following are available online at https:/ /www.mdpi.com/article/10 .3390/nano11071695/s1, Table S1: The IC50 of $\mathrm{Fe}_{3} \mathrm{O}_{4} @ \mathrm{Au}-\mathrm{dsDNA} / \mathrm{DOX}$ for Hela and MCF-7 cells, Figure S1: Calibration curve of the fluorescence and DOX fluorescence intensity as a function of the DOX and DNA concentration. The plot of $\log \left(\mathrm{F}_{0}-\mathrm{F}\right) / \mathrm{F}$ as a function of $\log [\mathrm{DNA}]$ was used to calculate the number of bound DOX molecules $(n)$ per DNA, Figure S2: Relationship between the percentage released after applying HFMF for $20 \mathrm{~min}$.

Author Contributions: Conceptualization, methodology, investigation, data Curation, formal Analysis, writing - original draft, B.-W.D.; methodology, investigation, data curation, formal Analysis, C.-Y.C.; resources, formal analysis, validation, C.-C.L.; supervision, project administration, writingreview \& editing, F.-H.K. All authors have read and agreed to the published version of the manuscript.

Funding: This research was funded by Ministry of Science and Technology of Taiwan under grant number "MOST-109-2113-M-009-013 and MOST 109-2224-E-007-004" and the APC was funded by "Ministry of Science and Technology of Taiwan".

Institutional Review Board Statement: Not applicable.

Informed Consent Statement: Not applicable.

Data Availability Statement: Data sharing not applicable.

Conflicts of Interest: There are no conflicts to declare.

\section{References}

1. Piorecka, K.; Smith, D.; Kurjata, J.; Stanczyk, M.; Stanczyk, W.A. Synthetic Routes to Nanoconjugates of Anthracyclines. Bioorg. Chem. 2020, 96, 103617. [CrossRef]

2. Doshi, N.; Swiston, A.J.; Gilbert, J.B.; Alcaraz, M.L.; Cohen, R.E.; Rubner, M.F.; Mitragotri, S. Cell-Based Drug Delivery Devices Using Phagocytosis-Resistant Backpacks. Adv. Mater. 2011, 23, H105-H109. [CrossRef] 
3. Sun, T.; Zhang, Y.S.; Pang, B.; Hyun, D.C.; Yang, M.; Xia, Y. Engineered Nanoparticles for Drug Delivery in Cancer Therapy. Angew. Chemie Int. Ed. 2014, 53, 12320-12364. [CrossRef] [PubMed]

4. Piorecka, K.; Kurjata, J.; Stanczyk, M.; Stanczyk, W.A. Synthetic Routes to Nanomaterials Containing Anthracyclines: Noncovalent Systems. Biomater. Sci. 2018, 6, 2552-2565. [CrossRef] [PubMed]

5. Spicer, C.D.; Jumeaux, C.; Gupta, B.; Stevens, M.M. Peptide and Protein Nanoparticle Conjugates: Versatile Platforms for Biomedical Applications. Chem. Soc. Rev. 2018, 47, 3574-3620. [CrossRef]

6. Gu, L.; Faig, A.; Abdelhamid, D.; Uhrich, K. Sugar-Based Amphiphilic Polymers for Biomedical Applications: From Nanocarriers to Therapeutics. Acc. Chem. Res. 2014, 47, 2867-2877. [CrossRef]

7. Luo, G.F.; Chen, W.H.; Lei, Q.; Qiu, W.X.; Liu, Y.X.; Cheng, Y.J.; Zhang, X.Z. A Triple-Collaborative Strategy for High-Performance Tumor Therapy by Multifunctional Mesoporous Silica-Coated Gold Nanorods. Adv. Funct. Mater. 2016, 26, 4339-4350. [CrossRef]

8. Ashton, S.; Song, Y.H.; Nolan, J.; Cadogan, E.; Murray, J.; Odedra, R.; Foster, J.; Hall, P.A.; Low, S.; Taylor, P.; et al. Aurora Kinase Inhibitor Nanoparticles Target Tumors with Favorable Therapeutic Index in Vivo. Sci. Transl. Med. 2016, 8, ra17-ra325. [CrossRef]

9. Kumar, A.; Huo, S.; Zhang, X.; Liu, J.; Tan, A.; Li, S.; Jin, S.; Xue, X.; Zhao, Y.; Ji, T.; et al. Neuropilin-1-Targeted Gold Nanoparticles Enhance Therapeutic Efficacy of Platinum(IV) Drug for Prostate Cancer Treatment. ACS Nano 2014, 8, 4205-4220. [CrossRef]

10. Sugumaran, P.J.; Liu, X.L.; Herng, T.S.; Peng, E.; Ding, J. GO-Functionalized Large Magnetic Iron Oxide Nanoparticles with Enhanced Colloidal Stability and Hyperthermia Performance. ACS Appl. Mater. Interfaces 2019, 11, 22703-22713. [CrossRef]

11. Bauer, I.; Knölker, H.J. Iron Catalysis in Organic Synthesis. Chem. Rev. 2015, 115, 3170-3387. [CrossRef] [PubMed]

12. Chao, Y.; Chen, G.; Liang, C.; Xu, J.; Dong, Z.; Han, X.; Wang, C.; Liu, Z. Iron Nanoparticles for Low-Power Local Magnetic Hyperthermia in Combination with Immune Checkpoint Blockade for Systemic Antitumor Therapy. Nano Lett. 2019, 19, 4287-4296. [CrossRef]

13. Park, J.H.; Von Maltzahn, G.; Zhang, L.; Schwartz, M.P.; Ruoslahti, E.; Bhatia, S.N.; Sailor, M.J. Magnetic Iron Oxide Nanoworms for Tumor Targeting and Imaging. Adv. Mater. 2008, 20, 1630-1635. [CrossRef] [PubMed]

14. Yang, H.W.; Hua, M.Y.; Liu, H.L.; Huang, C.Y.; Wei, K.C. Potential of Magnetic Nanoparticles for Targeted Drug Delivery. Nanotechnol. Sci. Appl. 2012, 5, 73-86. [PubMed]

15. Cardoso, V.F.; Francesko, A.; Ribeiro, C.; Bañobre-López, M.; Martins, P.; Lanceros-Mendez, S. Advances in Magnetic Nanoparticles for Biomedical Applications. Adv. Healthc. Mater. 2018, 7, 1-35. [CrossRef]

16. Jeon, S.; Park, B.C.; Lim, S.; Yoon, H.Y.; Jeon, Y.S.; Kim, B.S.; Kim, Y.K.; Kim, K. Heat-Generating Iron Oxide Multigranule Nanoclusters for Enhancing Hyperthermic Efficacy in Tumor Treatment. ACS Appl. Mater. Interfaces 2020, 12, 33483-33491. [CrossRef]

17. Hu, Y.; Wang, R.; Wang, S.; Ding, L.; Li, J.; Luo, Y.; Wang, X.; Shen, M.; Shi, X. Multifunctional Fe $\mathrm{O}_{4} @$ Au Core/Shell Nanostars: A Unique Platform for Multimode Imaging and Photothermal Therapy of Tumors. Sci. Rep. 2016, 6, 10-21. [CrossRef]

18. Li, W.P.; Liao, P.Y.; Su, C.H.; Yeh, C.S. Formation of Oligonucleotide-Gated Silica Shell-Coated Fe ${ }_{3} \mathrm{O}_{4}$-Au Core-Shell Nanotrisoctahedra for Magnetically Targeted and near-Infrared Light-Responsive Theranostic Platform. J. Am. Chem. Soc. 2014, 136, 10062-10075. [CrossRef]

19. Khan, M.S.; Vishakante, G.D.; Siddaramaiah, H. Gold Nanoparticles: A Paradigm Shift in Biomedical Applications. Adv. Colloid Interface Sci. 2013, 199-200, 44-58. [CrossRef]

20. Kwon, S.P.; Jeon, S.; Lee, S.H.; Yoon, H.Y.; Ryu, J.H.; Choi, D.; Kim, J.Y.; Kim, J.; Park, J.H.; Kim, D.E.; et al. Thrombin-Activatable Fluorescent Peptide Incorporated Gold Nanoparticles for Dual Optical/Computed Tomography Thrombus Imaging. Biomaterials 2018, 150, 125-136. [CrossRef]

21. Liu, J.; Xiong, Z.; Zhang, J.; Peng, C.; Klajnert-Maculewicz, B.; Shen, M.; Shi, X. Zwitterionic Gadolinium(III)-Complexed Dendrimer-Entrapped Gold Nanoparticles for Enhanced Computed Tomography/Magnetic Resonance Imaging of Lung Cancer Metastasis. ACS Appl. Mater. Interfaces 2019, 11, 15212-15221. [CrossRef]

22. Fenton, O.S.; Olafson, K.N.; Pillai, P.S.; Mitchell, M.J.; Langer, R. Advances in Biomaterials for Drug Delivery. Adv. Mater. 2018, 30, 1-29. [CrossRef]

23. Ding, L.; Ren, J.; Zhang, D.; Li, Y.; Huang, X.; Ji, J.; Hu, Q.; Wang, H.; Ni, Y.; Hou, Y. The TLR3 Agonist Inhibit Drug Efflux and Sequentially Consolidates Low-Dose Cisplatin-Based Chemoimmunotherapy While Reducing Side Effects. Mol. Cancer Ther. 2017, 16, 1068-1079. [CrossRef] [PubMed]

24. Sondermann, P.; Szymkowski, D.E. Harnessing Fc Receptor Biology in the Design of Therapeutic Antibodies. Curr. Opin. Immunol. 2016, 40, 78-87. [CrossRef] [PubMed]

25. Kara, S.; Amon, L.; Lühr, J.J.; Nimmerjahn, F.; Dudziak, D.; Lux, A. Impact of Plasma Membrane Domains on IgG Fc Receptor Function. Front. Immunol. 2020, 11, 1320. [CrossRef]

26. Adams, G.P.; Weiner, L.M. Monoclonal Antibody Therapy of Cancer. Nat. Biotechnol. 2005, 23, 1147-1157. [CrossRef] [PubMed]

27. Mairal, T.; Cengiz Özalp, V.; Lozano Sánchez, P.; Mir, M.; Katakis, I.; O’Sullivan, C.K. Aptamers: Molecular Tools for Analytical Applications. Anal. Bioanal. Chem. 2008, 390, 989-1007. [CrossRef]

28. Moutsiopoulou, A.; Broyles, D.; Dikici, E.; Daunert, S.; Deo, S.K. Molecular Aptamer Beacons and Their Applications in Sensing, Imaging, and Diagnostics. Small 2019, 15, 1-18. [CrossRef]

29. Goddard, Z.R.; Marín, M.J.; Russell, D.A.; Searcey, M. Active Targeting of Gold Nanoparticles as Cancer Therapeutics. Chem. Soc. Rev. 2020, 8774-8789. [CrossRef]

30. Iliuk, A.B.; Hu, L.; Tao, W.A. Aptamer in Bioanalytical Applications. Anal. Chem. 2011, 83, 4440-4452. [CrossRef] 
31. Song, K.M.; Lee, S.; Ban, C. Aptamers and Their Biological Applications. Sensors 2012, 12, 612-631. [CrossRef] [PubMed]

32. Yang, X.; Liu, X.; Liu, Z.; Pu, F.; Ren, J.; Qu, X. Near-Infrared Light-Triggered, Targeted Drug Delivery to Cancer Cells by Aptamer Gated Nanovehicles. Adv. Mater. 2012, 24, 2890-2895. [CrossRef]

33. Pestourie, C.; Tavitian, B.; Duconge, F. Aptamers against Extracellular Targets for in Vivo Applications. Biochimie 2005, 87, 921-930. [CrossRef]

34. Chimene, D.; Alge, D.L.; Gaharwar, A.K. Two-Dimensional Nanomaterials for Biomedical Applications: Emerging Trends and Future Prospects. Adv. Mater. 2015, 27, 7261-7284. [CrossRef]

35. Dhall, A.; Self, W. Cerium Oxide Nanoparticles: A Brief Review of Their Synthesis Methods and Biomedical Applications. Antioxidants 2018, 7, 97. [CrossRef]

36. Jun, Y.W.; Huh, Y.M.; Choi, J.S.; Lee, J.H.; Song, H.T.; Kim, S.; Yoon, S.; Kim, K.S.; Shin, J.S.; Suh, J.S.; et al. Nanoscale Size Effect of Magnetic Nanocrystals and Their Utilization for Cancer Diagnosis via Magnetic Resonance Imaging. J. Am. Chem. Soc. 2005, 127, 5732-5733. [CrossRef]

37. Jiang, W.; Kim, B.Y.S.; Rutka, J.T.; Chan, W.C.W. Nanoparticle-Mediated Cellular Response Is Size-Dependent. Nat. Nanotechnol. 2008, 3, 145-150. [CrossRef] [PubMed]

38. Wang, S.; Fu, L.; Xin, J.; Wang, S.; Yao, C.; Zhang, Z.; Wang, J. Photoacoustic Response Induced by Nanoparticle-Mediated Photothermal Bubbles beyond the Thermal Expansion for Potential Theranostics. J. Biomed. Opt. 2018, 23, 1. [CrossRef] [PubMed]

39. Deng, X.; Li, K.; Cai, X.; Liu, B.; Wei, Y.; Deng, K.; Xie, Z.; Wu, Z.; Ma, P.; Hou, Z.; et al. A Hollow-Structured CuS@Cu 2 S@Au Nanohybrid: Synergistically Enhanced Photothermal Efficiency and Photoswitchable Targeting Effect for Cancer Theranostics. Adv. Mater. 2017, 29, 1-9. [CrossRef]

40. Wu, C.S.; Lee, C.C.; Wu, C.T.; Yang, Y.S.; Ko, F.H. Size-Modulated Catalytic Activity of Enzyme-Nanoparticle Conjugates: A Combined Kinetic and Theoretical Study. Chem. Commun. 2011, 47, 7446-7448. [CrossRef]

41. Kim, D.; Jeong, Y.Y.; Jon, S. A Drug-Loaded Aptamer - Gold Nanoparticle Bioconjugate for Combined Ct Imaging and Therapy of Prostate Cancer. ACS Nano 2010, 4, 3689-3696. [CrossRef] [PubMed]

42. Sjøgren, C.E.; Briley-Sæbø, K.; Hanson, M.; Johansson, C. Magnetic Characterization of Iron Oxides for Magnetic Resonance Imaging. Magn. Reson. Med. 1994, 31, 268-272. [CrossRef]

43. Agudelo, D.; Bourassa, P.; Bérubé, G.; Tajmir-Riahi, H.A. Intercalation of Antitumor Drug Doxorubicin and Its Analogue by DNA Duplex: Structural Features and Biological Implications. Int. J. Biol. Macromol. 2014, 66, 144-150. [CrossRef] [PubMed]

44. Putnam, D.; Zelikin, A.N.; Izumrudov, V.A.; Langer, R. Polyhistidine-PEG: DNA Nanocomposites for Gene Delivery. Biomaterials 2003, 24, 4425-4433. [CrossRef]

45. Yoo, H.S.; Park, T.G. In Vitro and in Vivo Anti-Tumor Activities of Nanoparticles Based on Doxorubicin-PLGA Conjugates. Am. Chem. Soc. Polym. Prepr. Div. Polym. Chem. 2000, 41, 992-993. [CrossRef]

46. Chatterjee, D.K.; Diagaradjane, P.; Krishnan, S. Nanoparticle-Mediated Hyperthermia in Cancer Therapy. Ther. Deliv. 2011, 2, 1001-1014. [CrossRef]

47. Storm, F.K. Clinical Hyperthermia and Chemotherapy. Radiol. Clin. North Am. 1989, 27, 621-627.

48. Kishimoto, M.; Yanagihara, H.; Kita, E. Dependences of Specific Loss Power on Magnetic Field and Frequency in Elongated Platelet $\gamma-\mathrm{Fe}_{2} \mathrm{O}_{3}$ Particles Using Hysteresis-Loss Heating. IEEE Trans. Magn. 2013, 49, 4756-4760. [CrossRef]

49. Hua, X.; Zhou, Z.; Yuan, L.; Liu, S. Selective Collection and Detection of MCF-7 Breast Cancer Cells Using Aptamer-Functionalized Magnetic Beads and Quantum Dots Based Nano-Bio-Probes. Anal. Chim. Acta 2013, 788, 135-140. [CrossRef] [PubMed] 